\title{
Water-Quality Assessment of Part of the Upper Mississippi River Basin, Minnesota and Wisconsin- Review of Selected Literature
}

By William J. Andrews, James D. Fallon, Sharon E. Kroening, Kathy E. Lee, and James R. Stark

U.S. Geological Survey

Water-Resources Investigations Report 96-4149

Contribution from the National Water-Quality Assessment Program 


\section{U.S. DEPARTMENT OF THE INTERIOR \\ BRUCE BABBITT, Secretary \\ U.S. GEOLOGICAL SURVEY \\ Gordon P. Eaton, Director}

For additional information write to:

District Chief

U.S. Geological Survey 2280 Woodale Drive

Mounds View, MN 55112
Copies of this report can be purchased from:

U.S. Geological Survey

Branch of Information Services

Open-File Reports Section

Box 25286

Denver, CO 80225-0286

Information regarding the National Water-Quality Assessment (NAWQA) Program is available on the Internet via the World Wide Web. You may connect to the NAWQA Home Page using the Universal Resource Locator (URL) at:

<URL:http://wwwrvares.er.usgs.gov/nawqa/nawqa_home.html> 


\section{Foreword}

The mission of the U.S. Geological Survey (USGS) is to assess the quantity and quality of the earth resources of the Nation and to provide information that will assist resource managers and policy makers at Federal, State, and local levels in making sound decisions. Assessment of water-quality conditions and trends is an important part of this overall mission.

One of the greatest challenges faced by waterresources scientists is acquiring reliable information that will guide the use and protection of the Nation's water resources. That challenge is being addressed by Federal, State, interstate, and local water-resource agencies and by many academic institutions. These organizations are collecting water-quality data for a host of purposes that include: compliance with permits and water-supply standards; development of remediation plans for a specific contamination problem; operational decisions on industrial, wastewater, or water-supply facilities; and research on factors that affect water quality. An additional need for water-quality information is to provide a basis on which regional and national-level policy decisions can be based. Wise decisions must be based on sound information. As a society we need to know whether certain types of water-quality problems are isolated or ubiquitous, whether there are significant differences in conditions among regions, whether the conditions are changing over time, and why these conditions change from place to place and over time. The information can be used to help determine the efficacy of existing water-quality policies and to help analysts determine the need for and likely consequences of new policies.

To address these needs, the Congress appropriated funds in 1986 for the USGS to begin a pilot program in seven project areas to develop and refine the National Water-Quality Assessment (NAWQA) Program. In 1991, the USGS began full implementation of the program. The NAWQA Program builds upon an existing base of water-quality studies of the USGS, as well as those of other Federal, State, and local agencies. The objectives of the NAWQA Program are to:

- Describe current water-quality conditions for a large part of the Nation's freshwater streams, rivers, and aquifers.

- Describe how water quality is changing over time.

- Improve understanding of the primary natural and human factors that affect water-quality conditions.

This information will help support the development and evaluation of management, regulatory, and monitoring decisions by other Federal, State, and local agencies to protect, use, and enhance water resources.
The goals of the NAWQA Program are being achieved through ongoing and proposed investigations of 60 of the Nation's most important river basins and aquifer systems, which are referred to as study units. These study units are distributed throughout the Nation and cover a diversity of hydrogeologic settings. More than two-thirds of the Nation's freshwater use occurs within the 60 study units and more than two-thirds of the people served by public water-supply systems live within their boundaries.

National synthesis of data analysis, based on aggregation of comparable information obtained from the study units, is a major component of the program. This effort focuses on selected water-quality topics using nationally consistent information. Comparative studies will explain differences and similarities in observed water-quality conditions among study areas and will identify changes and trends and their causes. The first topics addressed by the national synthesis are pesticides, nutrients, volatile organic compounds, and aquatic biology. Discussions on these and other waterquality topics will be published in periodic summaries of the quality of the Nation's ground and surface water as the information becomes available.

This report is an element of the comprehensive body of information developed as part of the NAWQA Program. The program depends heavily on the advice, cooperation, and information from many Federal, State, interstate, Tribal, and local agencies and the public. The assistance and suggestions of all are greatly appreciated.

Robert M. Hirsch

Chief Hydrologist 


\section{Contents}

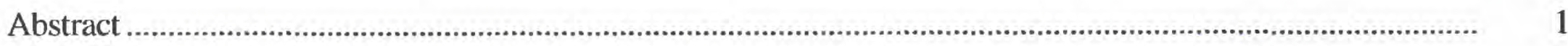

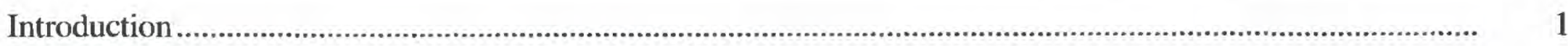

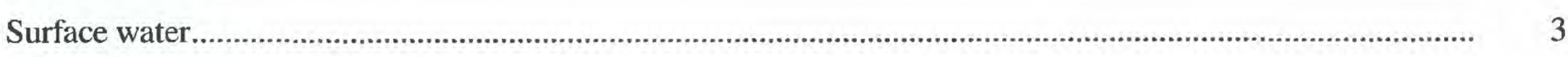

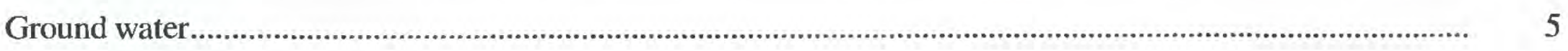

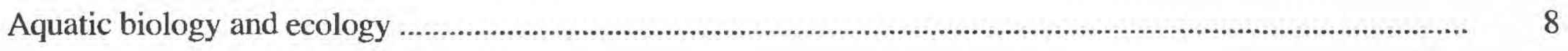

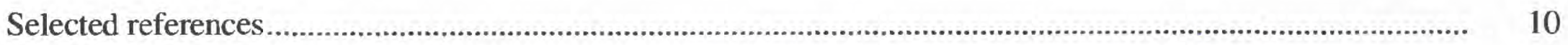

\section{Illustrations}

Figure 1-3. Maps showing:

1. Location of the Upper Mississippi River Basin NAWQA study unit, focused study area, hydrography, selected towns, and major cities

2. Surficial geology of the Upper Mississippi River Basin study unit

3. Bedrock hydrogeology of the Upper Mississippi River Basin study unit

\section{Conversion Factors and Abbreviations}

Multiply

square mile $\left(\mathrm{mi}^{2}\right)$
By

2.590
To obtain

square kilometer

Chemical concentrations: Chemical concentrations of substances in water are given in metric units of micrograms per liter $(\mu \mathrm{g} / \mathrm{L})$. Micrograms per liter is a unit expressing the concentration of chemical constituents in solution as mass (micrograms) of solute per unit volume (liter) of water. One thousand micrograms per liter is equivalent to one milligram per liter.

MDH-Minnesota Department of Health

MPCA—Minnesota Pollution Control Agency

MRAP—Minnesota River Assessment Program

NASQAN—National Stream Water Quality Accounting Network

NAWQA - National Water-Quality Assessment

TCMA-Twin Cities metropolitan area

UMIS-Upper Mississippi River Basin

USGS-U.S. Geological Survey

VOC's-Volatile organic compounds

Use of trade names in this report is for identification purposes only and does not constitute endorsement by the U.S. Geological Survey. 


\title{
Water-Quality Assessment of Part of the Upper Mississippi River Basin, Minnesota and Wisconsin- \\ Review of Selected Literature
}

\section{By William J. Andrews, James D. Fallon, Sharon E. Kroening, Kathy E. Lee, and James R. Stark}

\begin{abstract}
The U.S. Geological Survey began full-scale implementation of the National Water-Quality Assessment (NAWQA) Program in 1991. The purposes of NAWQA are to describe the status and trends in the quality of the Nation's water resources and aquatic ecosystems, and to determine factors affecting water quality at local, regional, and national scales. The Upper Mississippi River (UMIS) NAWQA study unit, which includes all of the surface drainage to the Mississippi River Basin upstream from Lake Pepin, encompasses 47,000 $\mathrm{mi}^{2}$. The study characterizes the geographic and seasonal distribution of water quality and aquatic biota in relation to anthropogenic activities and natural features. The initial phase of the UMIS study, during 1994-99, is focused on an area in Minnesota and Wisconsin that includes the seven-county Twin Cities (Minneapolis and St. Paul) metropolitan area. This report summarizes selected sources of information that are being used to aid in understanding water-quality issues and processes that form the basis of the sampling design for the study. This literature review includes sources of information about surface- and ground-water hydrology, water quality, and aquatic biology and ecology.
\end{abstract}

\section{Introduction}

The USGS began full scale implementation of the NAWQA Program in 1991. The purposes of the NAWQA Program are to describe the status and trends in the quality of the Nation's water resources and aquatic ecosystems, and to determine factors affecting water quality. Study-unit investigations are significant components of the program. Study units are made up of hydrologic systems that include parts of most major river basins and aquifer systems in the United States.

The UMIS NAWQA study unit includes all of the surface drainage to the Mississippi River Basin upstream from Lake Pepin and encompasses $47,000 \mathrm{mi}^{2}$ (fig. 1). The Upper Mississippi River Basin was selected as a study unit because water quality of the Mississippi River, the largest river in the Nation, is of national concern.

The purposes of the UMIS NAWQA study are to describe the status and trends in quality of water resources and to provide an understanding of factors affecting water quality and ecosystem status within the study unit. During the initial phase of the study (199499), emphasis is focused on a $19,500 \mathrm{mi}^{2}$ area in
Minnesota and Wisconsin that includes the sevencounty Twin Cities (Minneapolis and St. Paul) metropolitan area. The study area includes the UMIS drainage from Lake Pepin upstream to include all of the St. Croix River Basin and to points on the Minnesota (Jordan, Minnesota) and Mississippi (Royalton. Minnesota) Rivers where long-term water-quality data are available (fig. 1). During the initial phase of the study, the focus is on the most prominent water-quality and ecosystem issues, principally the effects of the TCMA on water quality and aquatic ecosystems. The study characterizes the geographic and seasonal variations of water quality, aquatic biota, and aquatichabitat conditions in relation to anthropogenic activities and natural features. Pesticides, nutrients, volatileorganic chemicals, and biological conditions are of specific interest to NAWQA from a national perspective (Gilliom and others, 1995).

This report describes selected published information on the surface- and ground-water hydrology, water quality, and aquatic biology and ecology of the UMIS study unit. This report summarizes important sources of information that are being used to aid in understanding water-quality issues and processes that form the basis of 


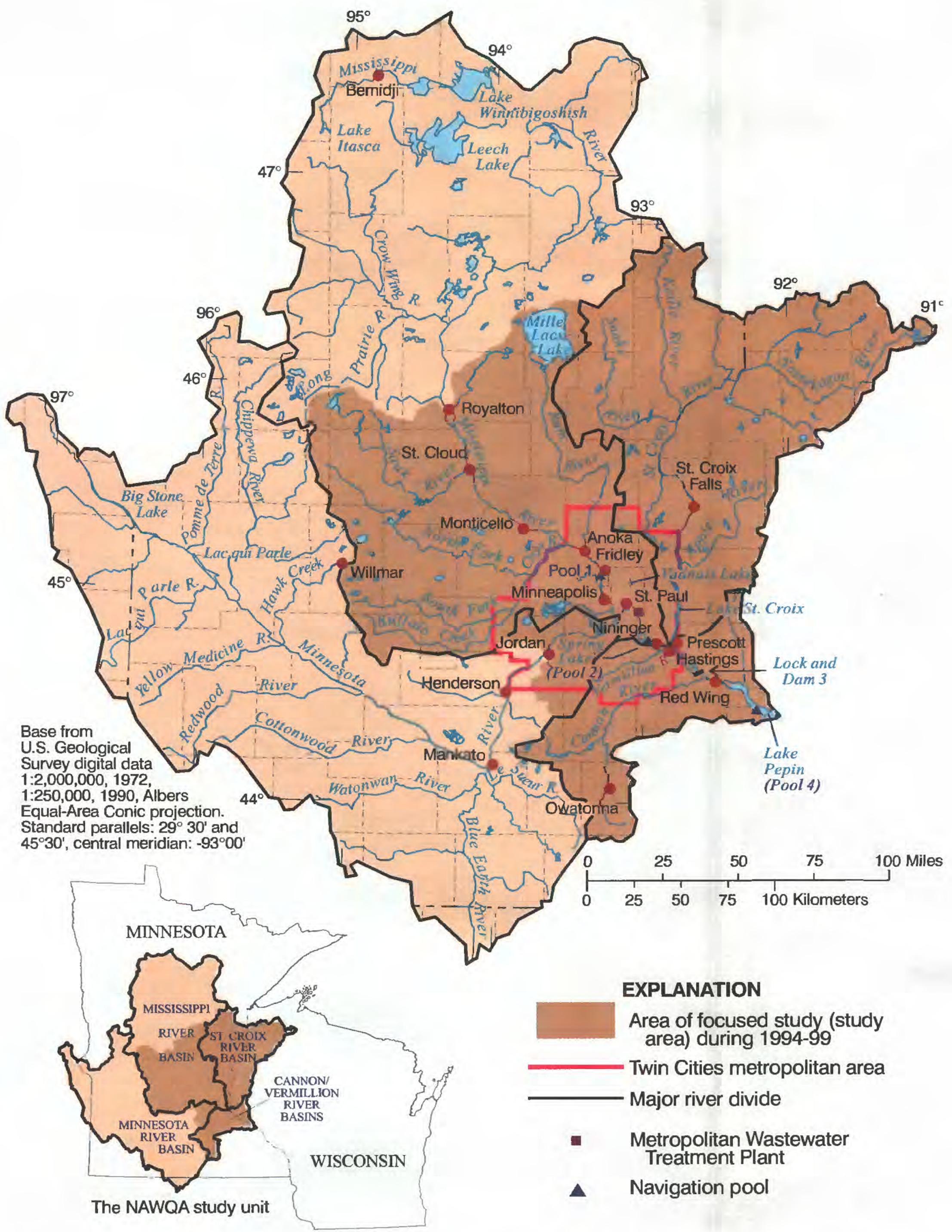

Figure 1.-Location of the Upper Mississippi River Basin NAWQA study unit, focused study area, hydrography, selected towns, and major cities. 
the sampling design for the study. Water quality in the study unit is affected by natural and anthropogenic factors. Natural factors include climate, physiography, geology, soils, topography, vegetation and aquatic biology. Anthropogenic factors include hydrologic modification, point- and nonpoint-source contaminant discharges, and changes to land use and to land cover.

Water-quality issues of local importance, and important to the program at a national level, have been defined by the study's liaison committee composed of representatives from Federal, state, and local agencies, private industry, and by NAWQA Program leadership. These issues have guided the literature review. Important sources of information include the Metropolitan Council Environmental Services, Minnesota Department of Agriculture, Minnesota Department of Health, Minnesota Department of Natural Resources, Minnesota Geological Survey, Minnesota Pollution Control Agency, University of Minnesota, U.S. Geological Survey, Wisconsin Department of Natural Resources, and Wisconsin Geological Survey. The list of publications completed for this effort consists of approximately 2,000 citations. Literature data bases searched include Aquatic Sciences and Fisheries Abstracts, Biosis, Compendex Plus, Dissertation Abstracts, Enviroline, Georef, Pollution Abstracts, and Water Resources Abstracts. The list of citations is available at the UMIS Home Page on the World Wide Web at: "http://wwwmn.cr.usgs.gov/umis/index.html".

\section{Surface Water}

General descriptions of surface-water hydrology of the Upper Mississippi River Basin are presented by Gunard and others (1986) for Minnesota and by Gebert (1986) for Wisconsin. The USGS has published a series of hydrologic atlases summarizing the water resources of watersheds in the Minnesota, Mississippi, and St. Croix River Basins. These hydrologic atlases include information on climate, streamflow, physical features, and surface- and ground-water resources. In the Minnesota River Basin, hydrologic atlases have been published for Big Stone Lake Watershed (Cotter and others, 1966), Blue Earth River (Anderson and others, 1974a), Chippewa River (Cotter and others, 1968), Cottonwood River (Broussard and others, 1973), Minnesota River and Hawk Creek (Van Voast and others, 1972), Lac qui Parle River (Cotter and Bidwell, 1968), Lower Minnesota River (Anderson and others, 1974b), Pomme de Terre River (Cotter and Bidwell, 1966), Redwood River (Van Voast and others, 1970), and Yellow Medicine River (Novitzki and others, 1969). The locations of cities and towns, rivers, lakes, and reservoirs cited in this section are shown in figure 1. Hydrologic atlases of basins in the Mississippi River Basin include the Cannon River (Anderson and others, 1974), Crow Wing River (Lindholm and others, 1972), Mississippi River headwaters (Oakes and Bidwell, 1968), Mississippi and Sauk Rivers (Helgesen and others, 1975), and Rum River (Ericson and others, 1974). In the St. Croix River Basin, published hydrologic atlases include the Kettle River (Helgesen and others, 1973), Snake River (Lindholm and others, 1974a), the Wisconsin portion of the St. Croix River (Young and Hindall, 1973), and the Minnesota portion of the Lower St. Croix River (Lindholm and others, 1974b).

Physical characteristics including drainage area, stream order, channel length and slope, lake area, and storage area have been published for subbasins of the Minnesota River in U.S. Geological Survey Open-File Reports for the Blue Earth (Lorenz and Payne, 1992), Chippewa (Sanocki and Kumrie, 1994), Cottonwood (Sanocki, 1995b), Lac qui Parle (Lorenz and others, 1994), Le Sueur (Lorenz and Payne, 1991a), Pomme de Terre (Lorenz and Payne, 1994), Redwood (Lorenz and Payne, 1989), and Watonwan Rivers (Lorenz and Payne, 1991b), as well as western drainages of the Upper Minnesota River (Sanocki, 1995a).

Most interpretive literature related to surface-water hydrology of the Upper Mississippi River Basin is related to floods, low flow, or water availability. Floods of historical significance in Minnesota and Wisconsin are summarized by Carlson (1991) and Krug and Simon (1991). The 1993 floods in the Mississippi River Basin are summarized in a series of reports that include analysis of precipitation (Wahl and others, 1993) and flood discharges (Parrett and others, 1993; Southard, 1993). Parret and others (1993) describe flood discharges in five tributaries to the Minnesota River which exceeded peak flows for their respective periods of record. Southard (1993) presented calculations showing that discharge in the Mississippi River at St. Paul during a 27-day flooding period was more than twice the average annual runoff for the period of record. Several reports document flood-prone areas (Carlson, 1971; Guetzkow and Carlson, 1973; Carlson and Guetzkow, 1980) along the Mississippi, Minnesota, and St. Croix Rivers, and changes in flood-prone areas due to land use and navigation effects along the Mississippi River (Olson and Meyer, 1976).

Low streamflow conditions have been studied extensively, especially along the Mississippi River through the Twin Cities. The drought of 1988 prompted several investigations. The Minnesota Department of 
Natural Resources (1989) summarized climatic conditions that caused the drought, the effects on streamflow, lake levels, and regulatory activities. The Metropolitan Council (1992) presented a plan for the TCMA water supply. The report focuses on water use, availability, quality, and water-management recommendations in the TCMA. Schoenberg (1989) estimated that the amount of monthly mean flow of the Mississippi River at Prescott, Wisconsin, that was supplied by ground-water discharge varied from 15 percent during a typical wet year to 25 percent during a dry year.

The U.S. Army Corps of Engineers (1990) presented a water-control plan to guide discharge strategy for six headwater reservoirs used to sustain streamflow of the Mississippi River. Norvitch and others (1973) summarized water resources of the TCMA that included a surface-water budget as well as seasonal, long-term and low-flow analyses of streamflow.

Other interpretive studies focused on the effects of urban land use on streamflow and water quality (Ayers and others, 1985; Arntson and Lorenz, 1987). Ayers and others (1985) found total storm rainfall to be the most significant factor controlling the runoff and nutrient and sediment loads of 11 urban and rural watersheds in the TCMA. Brown (1985a) concluded that the amount of precipitation was the main factor affecting the quantity of runoff in selected TCMA watersheds lacking wetlands. Brown (1987) found that wetland channelization substantially decreased the volume of surface storage of runoff and nutrient and sediment load retention in the wetlands, and that erosion of the channelized wetlands was a major source of nutrient and sediment loading.

Several studies have investigated the interaction of lakes and ground water. Lake-level fluctuations were found to be controlled by ground-water discharge and leakage from lakes to ground water into and from the lakes (Brown, 1985b). Ruhl (1994) described net discharge of ground water into and out of Vadnais Lake, north of St. Paul, Minnesota (fig. 1) and found it to be small when compared to surface-water inflow and outflow. Ruhl concluded that seepage from the lake to ground water could enrich phosphorus concentrations in ground water.

Several reports have summarized water quality in streams of the Upper Mississippi River Basin. Have (1991) described spatial and temporal variability in stream-water quality, based on information collected by the USGS-NASQAN Program, for the Mississippi River and its tributaries from Royalton to Hastings,
Minnesota. Selected constituent concentrations, including physical parameters, nutrients, major ions, and trace metals were found to vary significantly among streams. The quality of water in the Mississippi River, downstream from the confluences of the Minnesota and St. Croix Rivers, was also shown to have been affected by discharge from the Minnesota River and by effluent discharge from the Metropolitan Wastewater Treatment Plant, downstream of St. Paul, Minnesota.

The Metropolitan Waste Control Commission (1993a) conducted a study of phosphorus in the Mississippi River from Anoka, Minnesota to the downstream part of Lake Pepin during 1990-92. The study evaluated phosphorus loadings from the Metropolitan Wastewater Treatment Plant and from other sources on the water quality of Spring Lake and Lake Pepin. Results included a summary (1976-91) of the water quality of the Mississippi River and its tributaries from Anoka, Minnesota to Lock and Dam 3 at Red Wing, Minnesota (Metropolitan Waste Control Commission, 1993b); a description of the relative contributions of point and nonpoint sources of phosphorus loadings to the Mississippi River (Metropolitan Waste Control Commission, 1993c); a summary of river-bed sediment and its potential contribution to water-column phosphorus concentrations in the Mississippi River and Lake Pepin (Metropolitan Waste Control Commission, 1993d); and results of simulating proposed phosphorus reductions on the water quality of Spring Lake and Lake Pepin (EnviroTech Associates, Inc., 1993a; EnviroTech Associates, Inc., 1993b; Minnesota Pollution Control Agency, 1993c).

Substantial loadings of nutrients, organic compounds, and trace metals enter the Upper Mississippi River at Pool 2, which receives treated effluents from the TCMA and inflow from the Minnesota River (Boyer, 1984; Metropolitan Waste Control Commission, 1993c and 1993d; Steingraeber and Wiener, 1995). The concentrations of polychlorinated biphenyls and trace metals in river sediment decreased downstream from the TCMA (Bailey and Rada, 1984; Beauvais and others. 1995; Dukerschein and others, 1992; Steingraeber and others, 1994; Wiener and others, 1984). Cadmium concentration in sediment downstream from Pool 2 exceeded 2.0 micrograms per gram (Beauvais and others, 1995).

The depletion of oxygen in the Mississippi River downstream from the TCMA, as related to the discharge of sewage into the river and the adverse effect on water quality downstream from Pool 4 is discussed by Wiebe (1927) and Fremling $(1964 ; 1989)$. In the early 1980's, 
dissolved oxygen concentrations in this reach of the river increased in response to improved treatment of wastewater from the TCMA (Fremling, 1989; Johnson and Aasen, 1989; Fremling and Johnson, 1990).

Maschwitz (1984) analyzed ammonia-nitrogen concentrations in the Mississippi River within the TCMA to determine an effluent limitation for the Metropolitan Wastewater Treatment Plant. The loading of ammonia to the Mississippi River from the Metropolitan Wastewater Treatment Plant was about equal to the load upstream of the plant during mean summer flow. The results of the study showed total and un-ionized ammonia concentrations in the Mississippi River generally increased downstream from the treatment-plant outfall. Total ammonia concentrations generally decreased in Spring Lake because of algal uptake of ammonia. In contrast, un-ionized ammonia concentrations remained fairly constant through Spring Lake. During extreme low-flow conditions, large concentrations of un-ionized ammonia were measured in Spring Lake and were attributed to greater algal activity (Maschwitz, 1984).

The MRAP, a cooperative study by Federal, State, and local agencies and coordinated by the MPCA, was conducted during 1989-93 to determine sources of point and nonpoint nutrient and sediment loading to the Minnesota River and the effects of this loading on water quality and river ecology. Results were compiled in five volumes, each containing several individual reports (Minnesota Pollution Control Agency, 1994a-1994e). This work included results from monitoring the Minnesota River and its tributaries from Lac qui Parle Reservoir to Henderson Reservoir, Minnesota (Payne, 1991; 1994), and results from monitoring the Lower Minnesota River and its tributaries from Jordan, Minnesota to the confluence with the Mississippi River (Metropolitan Waste Control Commission, 1994b).

Graczyk (1986) described the stream-water quality in the St. Croix National Scenic Riverway. Troelstrup and others (1993b) described water quality in the Lower St. Croix River from St. Croix Falls, Wisconsin, to the confluence with the Mississippi River.

\section{Ground Water}

The geology and hydrogeology of the study unit have been the subject of several comprehensive reports. Olcott (1992) summarized the ground-water resources of Iowa, Michigan, Minnesota, and Wisconsin. Young (1992a: 1992b), Mandle and Konitz (1992), and Siegel (1989) presented results of a study of the CambrianOrdovician aquifer system in the northern midwest as part of the USGS Regional Aquifer System Analysis Program. Sims and Morey (1972) presented a series of papers describing the geologic setting and origins of unconsolidated deposits (fig. 2) and rocks (fig. 3) of Precambrian-Cenozoic age in Minnesota. Generalized hydrogeology and the quality of water in the major aquifers in Minnesota were summarized in USGS reports by Anderson (1986); Lindholm and Norvitch (1976); Ruhl (1987); Ruhl and others (1982); Ruhl and Wolf $(1983,1984)$; and Woodward and Anderson (1986). Delin and Woodward (1984) and Woodward (1986) described the hydrogeologic setting, hydraulic properties, and potentiometric surfaces of regional aquifers in the Hollandale Embayment (fig. 3) of southeastern Minnesota. Norvitch and others (1973) described the general hydrologic framework of the TCMA. Schoenberg (1990) described the geologic and hydrologic setting of the TCMA and the development and application of a model to simulate ground-water flow in bedrock aquifers in the TCMA during 1970-79. Hult and Schoenberg (1984) presented an analysis of the ground-water hydrology of a part of the western TCMA as part of an evaluation of ground-water contamination.

Maps of potentiometric altitudes have been constructed for many of the principal aquifers in the TCMA. Potentiometric maps have been prepared by Andrews and others (1995), Delin and Woodward (1984), the Minnesota Department of Natural Resources, Division of Waters (1961), Reeder (1966), and Schoenberg (1984) for the Prairie du Chien-Jordan and Mt. Simon-Hinckley aquifers; by Norvitch and others (1973) for the St. Peter, Prairie du Chien-Jordan, and Mt. Simon-Hinckley aquifers: and by LarsonHigdem and others (1975) and Palen and others (1993) for the unconsolidated aquifers of glacial and alluvial origins. Kanivetsky (1977) estimated available groundwater resources in Minnesota. The Minnesota Geological Survey has published a series of detailed hydrogeologic county atlases which include maps of potentiometric altitudes and well yields for major aquifers in parts of the TCMA (Balaban, 1989; Balaban and Hobbs, 1990; Balaban and McSwiggen, 1982; Meyer and Swanson, 1992; Swanson and Meyer, 1990).

The quality of ground water in the study unit is generally satisfactory for most domestic, public, industrial, and irrigation uses (Kanivetsky, 1986). Most ground water is classified, on the basis of predominant ions, as a calcium-magnesium-bicarbonate type, with less than $1,000 \mathrm{mg} / \mathrm{L}$ dissolved solids (Adolphson and others, 1981). Statewide, concentrations of iron and manganese commonly exceed $300 \mu \mathrm{g} / \mathrm{L}$ and $50 \mu \mathrm{g} / \mathrm{L}$, respectively, which are the maximum recommended 


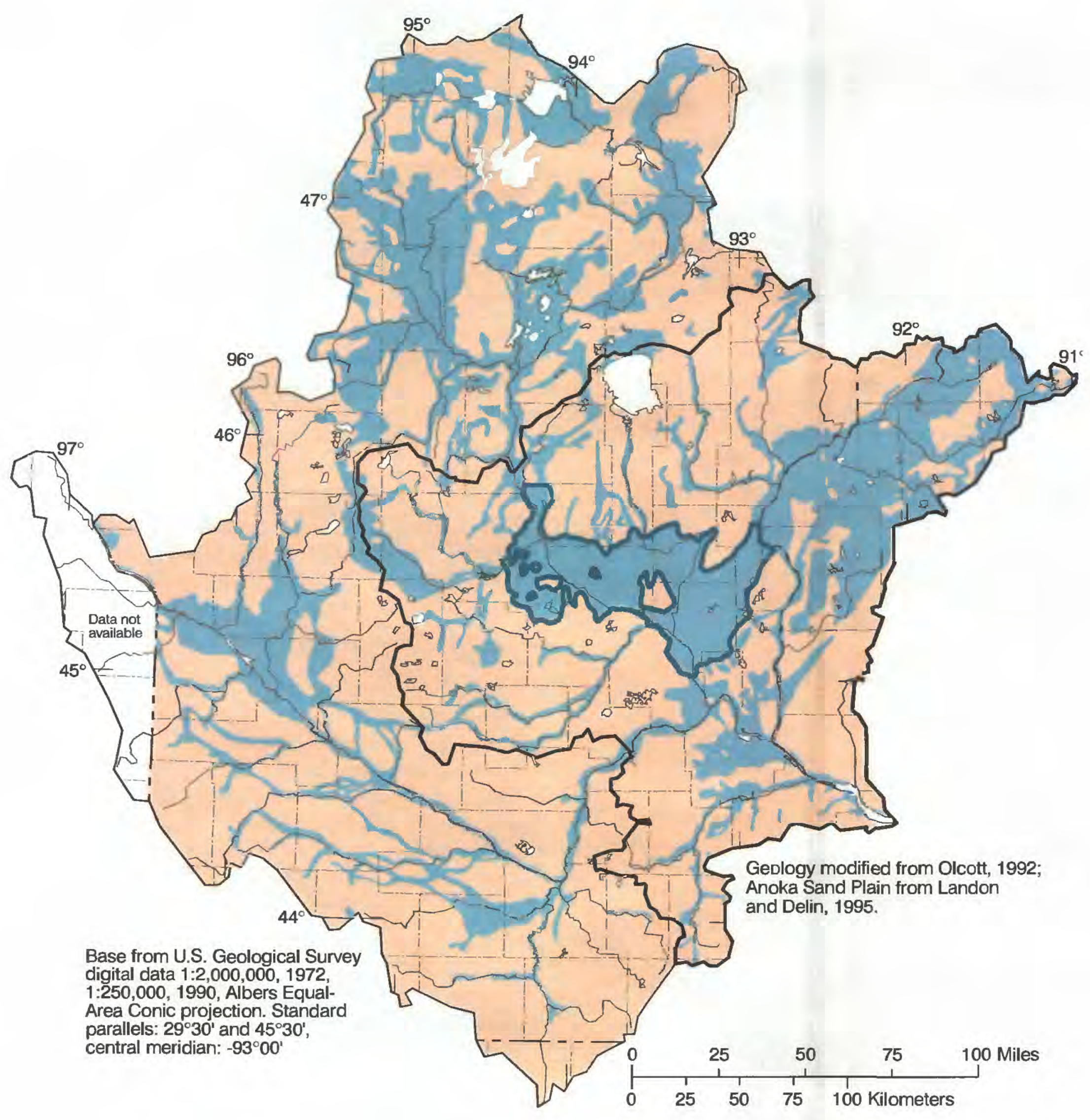

EXPLANATION

Glacial outwash, coarse-grained glacial-lake sediment or coarseand fine-grained alluvium of calcareous and siliceous deposits

Glacial till of calcareous and siliceous deposits

Study area boundary

Boundary of the Anoka Sand Plain

Figure 2.--Surficial geology in the Upper Mississippi River Basin study unit. 


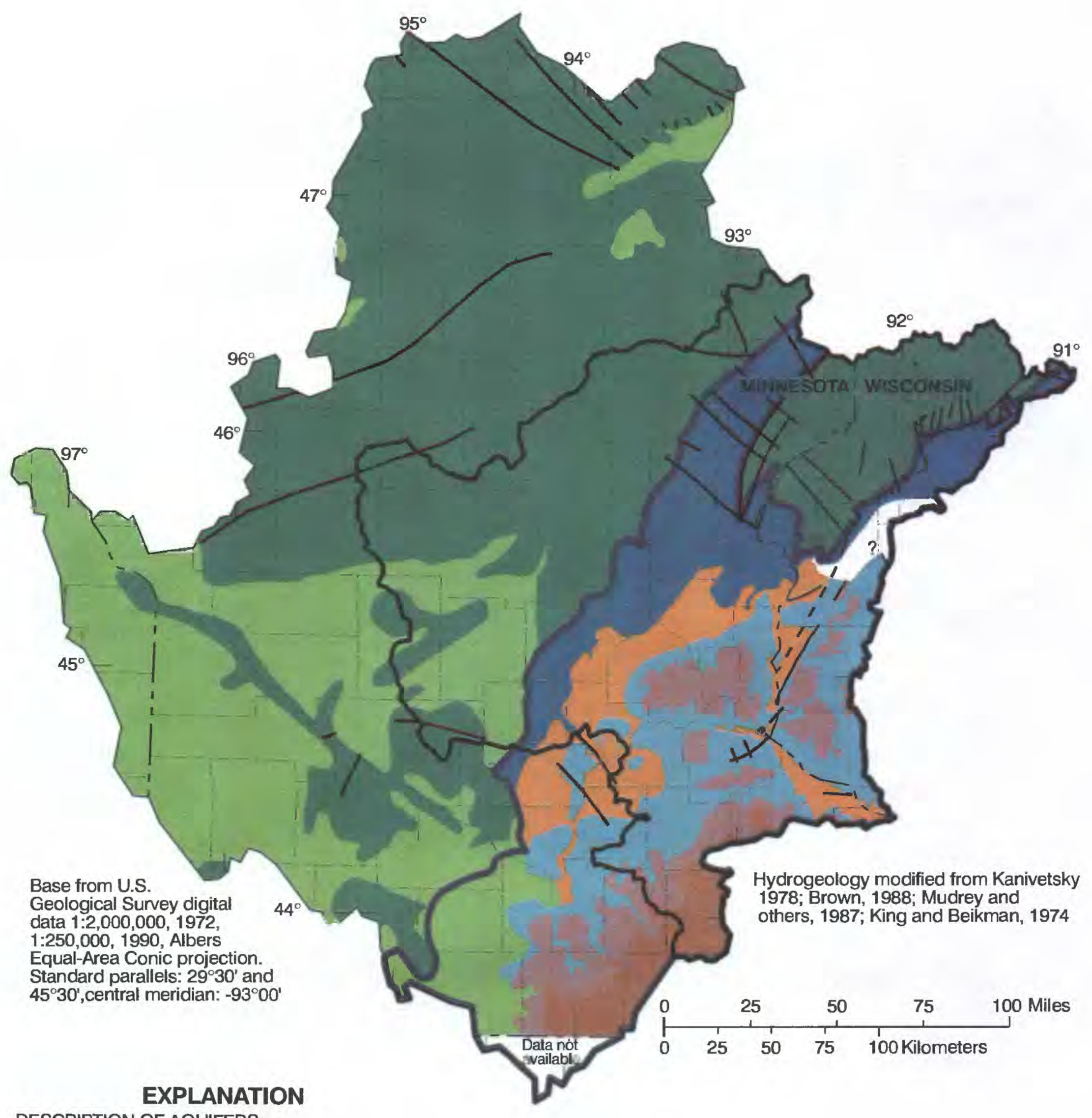

DESCRIPTION OF AQUIFERS:

Based upon State of Minnesota classification and terminology

CRETACEOUS
CEDAR VALLEY-MAQUOKETA-GALENA
*ST. PETER
*PRAIRIE DU CHIEN-JORDAN (in Minnesota)
PRAIRIE DU CHIEN-TREMPEALEAU (in Wisconsin)
*FRANCONIA-IRONTON-GALESVILLE (in Minnesota)
TUNNEL CITY-WONEWOC-EAU CLAIRE (in Wisconsin)

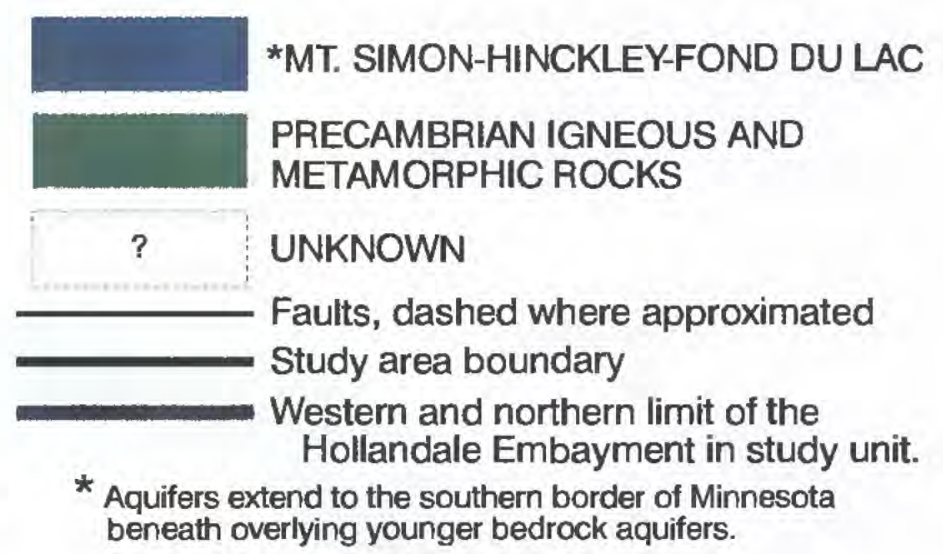

Figure 3.--Bedrock hydrogeology of the Upper Mississippi River Basin study unit. 
concentrations for these constituents in drinking water (U.S. Environmental Protection Agency, 1994).

The Cretaceous aquifer, present mainly in southwestern and western Minnesota (fig. 3), consists of shale and sandstone and is not commonly used as a source of water (Adolphson and others, 1981). Water from the Cretaceous aquifer, which is more mineralized than water from other aquifers in Minnesota, commonly contains 450 to $3,600 \mathrm{mg} / \mathrm{L}$ dissolved solids (Woodward and Anderson, 1986). Water in the Cedar ValleyMaquoketa-Galena aquifer (commonly referred to as the Upper Carbonate aquifer) has a median dissolved-solids concentration of about $280 \mathrm{mg} / \mathrm{L}$. Concentrations of sodium and sulfate increase to the southwest, where the aquifer is in contact with thick glacial drift and, possibly, with Cretaceous rocks (Ruhl and Wolf, 1984). Water from the St. Peter aquifer has dissolved-solids concentrations generally ranging from 260 to $950 \mathrm{mg} / \mathrm{L}$ (Ruhl and Wolf, 1983) and has a median concentration of about $360 \mathrm{mg} / \mathrm{L}$. Water from the Prairie du ChienJordan aquifer has a median dissolved-solids concentration of about $250 \mathrm{mg} / \mathrm{L}$ in most of southeastern Minnesota (Ruhl and others, 1983). Dissolved-solids concentrations in water in the western part of the aquifer range from 500 to $1,000 \mathrm{mg} / \mathrm{L}$ (Wolf and others, 1983). Water from the Mount SimonHinckley-Fond du Lac aquifer has concentrations of dissolved solids generally less than $500 \mathrm{mg} / \mathrm{L}$ (Wolf and others, 1983). Water in Precambrian igneous and metamorphic rocks has dissolved-solids concentrations generally less than $500 \mathrm{mg} / \mathrm{L}$ (Anderson, 1986).

Ground-water quality in Minnesota has been locally degraded by contamination. Major sources of groundwater contamination in Minnesota, according to the Minnesota Pollution Control Agency (1986), include: (1) spills or improper disposal of industrial or manufacturing chemicals, (2) leachate from solid-waste landfills, (3) spills and leaks from petroleum-product storage areas and pipelines, and (4) feedlots and agricultural chemicals. Volatile organic compounds are a type of chemical commonly released to ground water by many of those sources. A survey of 887 community water systems, which includes about 1,800 wells, was made for the purpose of detecting VOC's in drinking water (Minnesota Department of Health, 1985). The survey showed detectable VOC's in water from 109 wells. In 15 communities, the concentrations of VOC's in water from some of the public-supply wells exceeded standards set by the MDH (Minnesota Department of Health, 1985). Andrews and others (1996) determined that VOC's were detectable in samples from 5 percent or less of water from wells in the study area.

\section{Aquatic Biology and Ecology}

Numerous reports about aquatic biology and ecology have been published for the streams in the Upper Mississippi River Basin including several large studies that encompass the study unit, and many locally focused projects. The following information describes selected studies, organized by river basin. The locations of cities, towns, rivers, lakes, and reservoirs cited in this section are shown in figure 1 .

The Minnesota River has been the subject of various kinds of studies, including: a fisheries survey (Huber, 1959); an investigation of the Lower Minnesota River from Carver Rapids near Jordan, Minnesota to the confluence with the Mississippi River that included coliform, algae, invertebrates, fish and water quality (E.A. Hickock and Associates, 1978; Minnesota Department of Health, 1964); a water quality and fishery reconnaissance from Lac qui Parle to Mankato, Minnesota (Schneider, 1966); a detailed description of the environmental and economic settings (Southern Minnesota River Basin Commission. 1977); a biological survey of fish, invertebrates, and habitat (Kirsh and others, 1985); development potential and the MRAP (Minnesota Pollution Control Agency, 1994d), the most comprehensive biological study of the basin to date.

MRAP was a multidisciplinary and multiagency program to characterize physical, chemical, and biological conditions in the Minnesota River Basin and to recommend management practices for river restoration (Kavanaugh, 1993). Biological assessment consisted of a compilation of six components (Minnesota Pollution Control Agency, 1994d). Diatom community structure was evaluated in 16 streams during 1991-92, and suspended sediment and siltation were identified as factors that may affect the diatom species composition (Richards and Kutka, 1993). Benthic macroinvertebrate communities were assessed at 41 sites in streams during the summers of 1989-92 (Zischke and others, 1993). Stream conditions were found to be moderately to severely degraded at most sites with respect to the macroinvertebrate communities. Bailey and others (1993) evaluated fish communities at 116 sites, and reported that sedimentation had a negative affect on fish communities. Proctor (1993) analyzed trace elements and PCB's in sediments, settleable solids, and clam tissue during 1989-92. One clam species, Lampgilis ventricosa, was found to have accumulated high levels of copper, zinc, and nickel. Arthur and others (1993) used standard tests to determine toxicity of sediments and water to phytoplankton, zooplankton, and a freshwater amphipod. Scheld and others (1993) measured liver enzyme activity in fish to determine the 
effect of organic contaminants on fish, and showed that effects were greater in the Minnesota River than in tributaries during years with low flow. Fish in tributaries were most affected during periods of high flow following a drought year.

Several reports pertain to streams in the St. Croix River Basin. Fago and Hatch (1993) provide a summary of the geology, land use, surface-water quality, and aquatic biota in the St. Croix River Basin. Hanson and others (1987) presented results of a 1986-87 survey conducted by the Minnesota Department of Natural Resources at 20 sites on the Kettle River. Based on comparisons with an earlier study (Kittel, 1962), Hanson and others (1987) reported a decline in diversity of fish communities in portions of the river. Fish abundance in the Kettle River was generally lower than in similar-sized rivers due to low alkalinity, low total phosphorous, low total nitrogen, and the presence of tanic acid-stained water.

Montz and others (1989) presented results from stream monitoring during 1988-89 at 43 sites on the St. Croix River and compared results to a 1959 survey (Kuehn and others, 1961). Golden redhorse (Moxostoma erythrorum) were the most common fish species found in 1989. Lake sturgeon (Acipenser fulvescens) were commonly found in the 1959 survey, but were rare in the 1989 survey. Chironomidae (midges) and Trichoptera (caddis flies) comprised 54 percent of the 117 aquatic insect taxa collected. Invertebrate diversity was highest in 1989 in the Upper St. Croix River where the substrate was more heterogeneous (Montz and others, 1989).

Mathiak (1979) described the distribution and abundance of 45 species of unionid mussels in the St. Croix River and other Wisconsin streams. Boyle and others (1992) evaluated physical, chemical, and biological conditions in the St. Croix River using benthic macroinvertebrates as biological indicators. A general trend of increase in total dissolved phosphorus from upstream to downstream in the St. Croix River was attributed to changes from forest to agricultural land use. Invertebrate community structure was found to be more complex with respect to diversity and abundance above the dam at St. Croix Falls, Wisconsin than below the dam.

Many studies have focused on the aquatic ecology and biology of the Mississippi River. Wiebe (1927) conducted a study to determine the effects of contaminants from the TCMA on aquatic communities in the Upper Mississippi River. Moyle (1940) completed a biological survey of the Upper Mississippi River watershed. Enblom (1977) conducted a biological survey of the Upper Mississippi River from St. Cloud to Fridley, Minnesota. National Biocentric, Inc. (1979) collected fish, macroinvertebrates, and periphyton in the Mississippi River from Coon Rapids to Pool 2. Fremling and Clafin (1984) summarized the ecological history of the Upper Mississippi River since the 1800's.

Studies of the Mississippi River that focus on fish investigations have been completed. Eddy and others (1963) described fish communities above St. Anthony Falls in Minneapolis, Minnesota and discussed the Falls as a barrier to fish migration. Nord (1976) presented information on the presence and distribution of fish species by river pool, and Rasmussen (1979) updated that information. Scherer (1970) presented data for a 6mile reach of the Mississippi River near a nuclear power plant at Monticello, Minnesota. That study focused on data collection prior to plant operation with regard to fish population structure, species migration, condition of the species, and microhabitat. The Upper Mississippi River Conservation Committee (Pitlo and others, 1995) compiled a list of fish species present in the Upper Mississippi River from St. Paul, Minnesota to Cairo, Illinois. Three species-gizzard shad (Dorosoma cepedianum), emerald shiner (Notropis atherinoides), and common carp (Cyprinus carpio)-were considered common throughout the reach. Swenson and others (1989) described fish populations in the Upper Mississippi River and discussed the relation between stream discharge and the abundance of smallmouth bass (Micropterus dolomieui). That study, based on sampling near power plants near Monticello and Becker, Minnesota, reported 48 fish species at these two sites. Smallmouth bass were the only abundant game fish. Underhill (1989) described the distribution of fish in relation to Late Pleistocene glaciation. Poff and Allan (1995) found a relation between hydrologic variability and fish assemblages for 34 streams in Minnesota and Wisconsin. Lubinski and others (1986) summarized the introduction of common carp into the Mississippi River.

Several studies focused on macroinvertebrate taxa. Hornback and others (1989) reported that mayflies were the dominant macroinvertebrate taxa in a backwater lake of Pool 2, based on density and biomass, and that organic matter was the most important factor influencing the presence or absence of various taxa. The Academy of Natural Sciences completed a survey of unionid mussels in the Upper Mississippi River basin at 40 sites (Fuller, 1978). Mueller (1993) reported a decline in the populations of the winged mapleleaf mussel (Quadrula fragrosa) and the Higgin's eye pearly mussel (Lampsilis higginsi) in the Mississippi, Minnesota, and St. Croix Rivers since the 1800's, which 
was attributed to overharvesting, physical barriers which impede migration, habitat-quality degradation, barge traffic, contaminants, and introduction of exotic species. Wilson and others (1995) reported a decline in the populations of fingernail clams (Musculium transversum) in Pools 2, 5, 7, 9, and 19 on the Mississippi River for the period 1973-92. The decline of clam population in Pools 2 and 9 were linked to pointsource pollution.

Algal investigations within the Mississippi River include Baker and Baker (1979), who discussed the effects of temperature and stream discharge on the concentration and photosynthetic activity of phytoplankton near Red Wing in the Upper Mississippi River. Temperature and discharge were found to regulate phytoplankton concentration, chlorophyll- $a$, and light-saturated photosynthetic rates. An increase in discharge corresponded to an accompanying decrease in chlorophyll- $a$ and light-saturated photosynthetic rate. Minnesota Pollution Control Agency (1989) evaluated water quality in Lake Pepin during the summer of 1988 in response to two extensive fish kills that summer, which were attributed to low dissolved oxygen levels or elevated ammonia levels related to blue-green algal blooms. Results showed elevated chlorophyll- $a$ levels ranging from 50 to $200 \mu \mathrm{g} / \mathrm{L}$ and algal communities dominated by blue green taxa (Aphanizomenon spp. and Microcystis spp.) A series of studies focusing on attached algal communities in the Mississippi River near Monticello, Minnesota were completed during 1968-76 (Collingsworth, 1968, 1969; Collingsworth and Brook, 1970, 1971; Knutson, 1972a, 1972b, 1973, 1974, 1975, 1976).

\section{Selected References}

Adolphson, D.G., Ruhl, J.F., and Wolf, R.D., 1981, Designation of principal water-supply aquifers in Minnesota: U.S. Geological Survey WaterResources Investigations Report 81-51, 19 p.

Anderson, H.W., Jr., 1986, Hydrogeologic and waterquality characteristics of crystalline-rock aquifers of Archean and Proterozoic age, Minnesota: U.S. Geological Survey Water-Resources Investigations Report 86-4033, 2 plates.

Anderson, H.W., Jr., Farrell, D.F., and Broussard, W.L., 1974a, Water resources of the Blue Earth River watershed, south-central Minnesota: U.S. Geological Survey Hydrologic Investigations Atlas HA-525, 3 sheets, scale 1:500,000. 1974b, Water resources of the Lower Minnesota River watershed, south-central Minnesota: U.S. Geological Survey Hydrologic Investigations Atlas HA-526, 3 sheets, scale 1:500,000.

Anderson, H.W., Jr., Farrell, D.F., Broussard, W.L., and Felsheim, P.E., 1974, Water resources of the Cannon River watershed, southeastern Minnesota: U.S. Geological Survey Hydrologic Investigations Atlas HA-522, 3 sheets, scales 1:250,000 and $1: 500,000$.

Andrews, W.J., Fallon, J.D., and Kroening, S.E., 1996, Water-quality assessment of the Upper Mississippi River Basin, Minnesota and Wisconsin-Presence and distribution of volatile organic compounds in surface and ground water, 1978-94: U.S. Geological Survey Water-Resources Investigations Report 95-4216, 39 p.

Andrews, W.J., Trotta, L.C., and Schoenberg, M.E., 1995, Ground-water withdrawals and water-level declines from 1980-90 in the Prairie du ChienJordan and Mt. Simon-Hinckley aquifers, Twin Cities metropolitan area, Minnesota: Proceedings of the 31st Annual Conference of the American Water Resources Association, November 5-9, 1995, Houston, Texas, p. 63-72.

Arntson, A.D., and Lorenz, D.L., 1987, Low-flow frequency characteristics for continuous-record streamflow stations in Minnesota: U.S. Geological Survey Water-Resources Investigations Report 86$4353,15 \mathrm{p}$.

Arthur, J.W., Thompson, J.A., Walbridge, C.T., and Read, A.W., 1993, Ambient toxicity assessments in the Minnesota River Basin: U.S. Environmental Protection Agency, Environmental Research Library Duluth, Minnesota, Internal report 2737, variously paged.

Ayers, M.A., Brown, R.G., and Oberts, G.L., 1985, Runoff and chemical loading in small watersheds in the Twin Cities metropolitan area, Minnesota: U.S. Geological Survey Water-Resources Investigations Report 85-4122, 35 p. 
Bailey, P.A., Enblom J.W., Hanson, S.R., Renard, P.A., and Schmidt, K.S., 1993, Fish community analysis in the Minnesota River Basin: Minnesota Pollution Control Agency, St. Paul, Minnesota, variously paged.

Bailey, P.A., and Rada, R.G., 1984, Distribution and enrichment of trace metals $(\mathrm{Cd}, \mathrm{Cr}, \mathrm{Cu}, \mathrm{Ni}, \mathrm{Pb}, \mathrm{Zn})$ in bottom sediments of navigation pools 4 (Lake Pepin), 5, and 9 of the Upper Mississippi River, in Wiener, J.G., Anderson, R.V., and McConville, D.R., eds., Contaminants in the Upper Mississippi River: Butterworth Publishers, Boston, Massachusetts, p. 119-138.

Baker, A.L., and Baker, K.K., 1979, Effects of temperature and current discharge on the concentration and photosynthetic activity of the phytoplankton in the Upper Mississippi River: Freshwater Biology, v. 9, p. 191-198

Balaban, N.H., ed., 1989, Geologic atlas, Hennepin County, Minnesota: Minnesota Geological Survey County Atlas C-4, 9 plates.

Balaban, N.H., and Hobbs, H.C., eds., 1990, Geologic Atlas, Dakota County, Minnesota: Minnesota Geological Survey County Atlas C-6, 9 plates.

Balaban, N.H, and McSwiggen, P.L., eds., 1982, Geologic atlas, Scott County, Minnesota: Minnesota Geological Survey County Atlas C-1, 6 plates.

Beauvais, S.L., Wiener, J.G., and Atchision, G.J., 1995, Cadmium and mercury in sediment and burrowing mayfly nymphs (Hexagenia) in the Upper Mississippi River, USA: Archives of Environmental Contamination and Toxicology, v. 28, p. $178-183$.

Boyer, H.A., 1984, Trace elements in the water, sediments, and fish of the Upper Mississippi River, Twin Cities metropolitan area, in Wiener, J.G., Anderson, R.V., and McConville, D.R., eds., Contaminants in the Upper Mississippi River: Butterworth Publishers, Boston, Massachusetts, p. 195-230.

Boyle, T.P., Hoefs, N.J., and Beeson, D.R., 1992, An evaluation of the status of benthic macroinvertebrate communities in the Saint Croix
National Scenic Riverway, Minnesota and Wisconsin: National Park Service, Water Resources Division, Colorado State University, variously paged.

Broussard, W.L., Anderson, H.W., Jr., and Farrell, D.F., 1973, Water resources of the Cottonwood River watershed, southwestern Minnesota: U.S. Geological Survey Hydrologic Investigations Atlas HA-466, 3 sheets, scales 1:253,440 and 1:250,000.

Brown, B.A., 1988, Bedrock geology of Wisconsin: Wisconsin Geological and Natural History Survey Map 88-7, 1 sheet.

Brown, R.G., 1985a, Effects of wetlands on quality of runoff entering lakes in the Twin Cities metropolitan area, Minnesota: U.S. Geological Survey Water-Resources Investigations Report 85$4176,23 \mathrm{p}$.

1985b, Hydrologic factors affecting lake-level fluctuations in Big Marine Lake, Washington County, Minnesota: U.S. Geological Survey Water-Resources Investigations Report 85-4170, $32 \mathrm{p}$.

1987, Effects of wetland channelization of storm runoff in Lambert Creek, Ramsey County, Minnesota: Proceedings of the National Wetlands Symposium of Wetland Hydrology, Chicago, Illinois, September 16-18, 1987, p. 130-136.

Carlson, G.H., 1971, Flooded area of Lake St. Croix Beach, Minnesota: U.S. Geological Survey OpenFile Report, 4 p.

1991, Minnesota floods and drought, in Paulson, R.W., Chase, E.B., Williams, J.S., and Moody, D.W., compilers, National Water Summary 198889: U.S. Geological Survey Water-Supply Paper 2375, p. 345-352.

Carlson, G.H., and Guetzkow, L.C., 1980, Flood-plain areas of the Mississippi River mile 866.8 to mile 888.0: U.S. Geological Survey Water-Resources Investigations Report 80-972, 8 sheets. 
Collingsworth, R.F., 1968, Attached algae studies of the Mississippi River at Monticello, Minnesota: Northern States Power Company, Monticello Nuclear Generating Plant Annual Report-1968, p. 133-126.

1969, Attached algae studies of the Mississippi River at Monticello, Minnesota: Northern States Power Company, Monticello Nuclear Generating Plant Annual Report-1969, p. 1-30.

Collingsworth, R. F., and Brook, 1970, Attached algae studies of the Mississippi River at Monticello, Minnesota: Northern States Power Company, Monticello Nuclear Generating Plant Annual Report-1970, p. 251-304.

1971, Attached algae studies of the Mississippi River at Monticello, Minnesota: Northern States Power Company, Monticello Nuclear Generating Plant Annual Report-1971, p. 1-65.

Cotter, R.D., and Bidwell, L.E., 1966, Water resources of the Pomme de Terre River watershed, westcentral Minnesota: U.S. Geological Survey Hydrologic Investigations Atlas HA-220, 4 sheets, scale 1:250,000.

1968, Water resources of the Lac qui Parle River watershed, southwestern Minnesota: U.S. Geological Survey Hydrologic Investigations Atlas HA-269, 4 sheets, scale 1:250,000.

Cotter, R.D., Bidwell, L.E., Oakes, E.L., and Hollenstein, G.H., 1966, Water resources of the Big Stone Lake watershed, west-central Minnesota: U.S. Geological Survey Hydrologic Investigations Atlas HA-213, 4 sheets, scale 1:250,000.

Cotter, R.D., Bidwell, L.E., Van Voast, W.A., and Novitzki, R.P., 1968, Water resources of the Chippewa River watershed, west-central Minnesota: U.S. Geological Survey Hydrologic Investigations Atlas HA-286, 4 sheets, scale $1: 250,000$.

Dawson, V.K., Jackson, G.A., and Korschgen, C.E., 1984, Water chemistry at selected sites on pools 7 and 8 of the Upper Mississippi River-A ten-year survey, in Wiener, J.G., Anderson, R.V., and
McConville, D.R., eds., Contaminants in the Upper Mississippi River: Butterworth Publishers, Boston, Massachusetts, p. 279-291.

Delin, G.N., and Woodward, D.G., 1984,

Hydrogeologic setting and the potentiometric surfaces of the regional aquifers of the Hollandale Embayment, southeastern Minnesota, 1970-80:

U.S. Geological Survey Water-Supply Paper 2219, $56 \mathrm{p}$.

Dukerschein, J.T., Wiener, J.G., Rada, R.G., and Steingraeber, M.T., 1992, Cadmium and mercury in emergent mayflies (Hexagenia bilineata) from the Upper Mississippi River: Archives of Environmental Contamination and Toxicology, v. 23, p. 109-116.

E.A. Hickock, and Associates, 1978, Environment of the Lower Minnesota River-Social, administrative, and environmental constraints: E.A. Hickok, and Associates, Wayzata, Minnesota, 113 p. [available from the Metropolitan Waste Control Commission, St. Paul, Minnesota.]

Eddy, Samuel, Moyle J.B., and Underhill, J.C. 1963, The fish fauna of the Mississippi River above St. Anthony Falls as related to the effectiveness of these falls as a migration barrier: Minnesota Academy of Science Proceedings, v. 30, no. 2, p. 111-115.

Eddy, Samuel, and Underhill, J.C., 1974, Northern fishes, with special reference to the Upper Mississippi Valley: University of Minnesota Press, Minneapolis, Minnesota, 414 p.

Enblom, J.W., 1977, Biological reconnaissance of the Upper Mississippi River: Minnesota Department of Natural Resources, Division of Fish and Wildlife, Ecological Services Special Publication no. $121,70 \mathrm{p}$.

EnviroTech Associates, Inc., 1993a, Mississippi River phosphorus study - Water-quality modeling of the Upper Mississippi River and Lake Pepin: EnviroTech Associates, Inc., Charlottesville, Virginia, $111 \mathrm{p}$. 
1993b, Mississippi River phosphorus studyWater-quality modeling of the Upper Mississippi River and Lake Pepin [Addendum I]: EnviroTech Associates, Inc., Charlottesville, Virginia, 24 p.

Ericson, D.W., Lindholm, G.F., and Helgesen, J.O., 1974, Water resources of the Rum River watershed, east-central Minnesota: U.S. Geological Survey Hydrologic Investigations Atlas HA-509, 3 sheets, scales 1:250,000 and $1: 500,000$.

Fago, Don, and Hatch, Jay, 1993, Aquatic resources of the St. Croix River Basin, in Hesse, L.W., Stalnaker, C.B., Benson, N.G., and Zuboy, J.R., eds., Proceeding of the Symposium on Restoration Planning for the Rivers of the Mississippi River Ecosystem: National Biological Survey Report 19, p. 23-56.

Fremling, C.R., 1964, Mayfly distribution indicates water quality on the Upper Mississippi River: Science, v. 146, p. 1164-1166.

1989, Hexagenia mayflies-Biological monitors of water quality in the Upper Mississippi River: Journal of the Minnesota Academy of Science, v. 55 , no. 1 , p. 139-143.

Fremling, C.R., and Claflin, T.O., 1984, Ecological history of the Upper Mississippi River, in Contaminants in the Upper Mississippi RiverProceedings of the 15th Annual Meeting of the Mississippi River Research Consortium, Butterworth Publishers, Boston, Massachusetts, p. 5-24.

Fremling, C.R., and Johnson, D.K., 1990, Recurrence of hexagenia mayflies demonstrates improved water quality in Pool 2 and Lake Pepin, Upper Mississippi River, in Campbell, I.C., ed., Mayflies and Stoneflies-Proceedings of the International Conference on Ephemeroptera: Klower Academic Publishers, Norvell, Massachusetts, v. 5, p. 243248.

Fuller, S.L.H., 1978, Fresh-water mussels (mollusca bivalvia unionidae) of the Upper Mississippi River-Observations at selected sites within the 9 foot channel navigation project on behalf of the
United States: Army Corps of Engineers Final Report 78-33: Academy of Natural Sciences, Philadelphia, Pennsylvania, 400 p.

Gebert, W.A., 1986, Wisconsin surface-water resources, in D.W. Moody and others, compilers, National water summary 1985-Hydrologic events and surface-water resources: U.S. Geological Survey Water-Supply Paper 2300, p. 485-492.

Gilliom, R.J., Alley, W.M., and Gutz, M.E., 1995, Design of the National Water-Quality Assessment Programs-Occurrence and distribution of waterquality conditions: U.S. Geological Survey Circular 112, $33 \mathrm{p}$.

Goolsby, D.A., Battaglin, W.A., and Thurman, E.M., 1993, Occurrence and transport of agricultural chemicals in the Mississippi River Basin, July through August 1993: U.S. Geological Survey Circular 1120-C, 22 p.

Graczyk, D.J., 1986, Water quality in the St. Croix National Scenic Riverway, Wisconsin: U.S. Geological Survey Water-Resources Investigations Report 85-4319, 48 p.

Guetzkov, L.C., and Carlson, G.H., 1973, Flood-plain areas of the Lower Minnesota River: U.S. Geological Survey Open-File Report 74-15, 12 sheets.

Gunard, K.T., Hess, J.H., Zirbel, J.L., Cornelius, C.E., 1986, Water-resource data-Minnesota, water year 1984, volume 2. Upper Mississippi and Missouri River Basins: U.S. Geological Survey Water-Data Report, MN-84-2, 211 p.

Hanson, S.R., Renard, P.A., Enblom, J.W., and Montz, G.R., 1987, Biological Survey of the Kettle River: Minnesota Department of Natural Resources, Division of Wildlife internal document, $41 \mathrm{p}$.

Have, M.R., 1991, Selected water-quality characteristics in the Upper Mississippi River Basin, Royalton to Hastings, Minnesota: U.S. Geological Survey Water-Resources Investigations Report 88-4053, $152 \mathrm{p}$. 
Helgesen, J.O., Ericson, D.W., and Lindholm, G.F., 1975, Water resources of the Mississippi and Sauk Rivers watershed, central Minnesota: U.S. Geological Survey Hydrologic Investigations Atlas HA-534, 3 sheets.

Helgesen, J.O., Lindholm, G.F., Broussard, W.L., and Ericson, D.W., 1973, Water resources of the Kettle River watershed, east-central Minnesota: U.S. Geological Survey Hydrologic Investigations Atlas HA-437, 4 sheets, scale 1:250,000.

Hora, M.E., 1984, Polychlorinated biphenyls (PCB's) in common carp (Cyprinus carpio) of the Upper Mississippi River, in Wiener, J.C., Andersen, P.U., and McConville, D.R., eds., Contaminants in the Upper Mississippi River: Butterworth Publishers, Boston, Massachusetts, p. 231-239.

Hornback, D.J., Deneka, Tony, Payne, B.S., and Miller, A.C., 1989, Benthic macroinvertebrate community structure in a backwater lake of Pool 2, Upper Mississippi River: Journal of Freshwater Ecology, v. 5 , no. 2 , p.131-138.

Huber, E.H., 1959, A fisheries survey of the Minnesota River, Mankato to mouth: Minnesota Department of Natural Resources, Division of Fish and Wildlife, Ecological Services Section, Special Publication no. 84, 49 p.

Hult, M.F., and Schoenberg, M.E., 1984, Preliminary evaluation of ground-water contamination by coaltar derivatives, St. Louis Park area, Minnesota: U.S.Geological Survey Water-Supply Paper 2211, $53 \mathrm{p}$.

Johnson, D.K., and Aasen, P.W., 1989, The Metropolitan Wastewater Treatment Plant and the Mississippi River-50 years of improving water quality: Journal of the Minnesota Academy of Science, v. 55, no. 1, p. 134-143.

Kanivetsky, Roman, 1977, Regional approach to estimating the ground-water resources of Minnesota: Minnesota Geological Survey Report of Investigation 122, $13 \mathrm{p}$.

1978, Hydrogeologic map of Minnesota, bedrock hydrogeology: Minnesota Geological Survey, State Map Series S-2, 2 sheets.
1986, Major-constituent chemistry of selected Phanerozoic aquifers in Minnesota: Minnesota Geological Survey, Miscellaneous Map Series, Map M-61, 2 sheets.

Kavanaugh, C.M., 1993, Minnesota River Basin assessment project, in Hesse, L.W., Stalnaker, C.B., Benson, N.G., and Zuboy, J.R., eds., Proceedings of the Symposium on Restoration Planning for the Rivers of the Mississippi River Ecosystem: National Biological Survey Report 19, p. 5-21.

King, P.B., and Beikman, H.M., compilers, 1974, Geologic map of the United States: U.S. Geological Survey, scale 1:2,500,000, 2 sheets.

Kirsh, N.A., Hanson, S.A., Renard, P.A., and Enblom, J.W., 1985, Biological survey of the Minnesota River: Minnesota Department of Natural Resources, Division of Fish and Wildlife, Special Publication no. $139,85 \mathrm{p}$.

Kittel, H.R., 1962, Fisheries stream survey report of the Kettle River: Unpublished report on file with Minnesota Department of Conservation, Division of Wildlife Research and Planning, 36 p.

Knutson, K.M., 1972a, Summary report on the distribution pattern and known effects of sulfate ions on plant and animal life in the midwest and Mississippi River Basin: Northern States Power Company, Minneapolis, Minnesota, p. 1-12.

1972b, Attached algae studies of the Mississippi River at Monticello, Minnesota: Northern States Power Company, Monticello Nuclear Generating Plant Annual Report-1972, p. C419-C556.

1973, Attached algae studies of the Mississippi River at Monticello, Minnesota: Northern States Power Company, Monticello Nuclear Generating Plant Annual Report-1973, p. C383-C512. 1974, Attached algae studies of the Mississippi River at Monticello, Minnesota: Northern States Power Company, Monticello Nuclear Generating Plant Annual Report-1974, p. 37-122. 
1975, Attached algae studies of the Mississippi River at Monticello, Minnesota: Northern States Power Company, Monticello Nuclear Generating Plant Annual Report-1975, p. 2.1-1-2.1-49.

1976, Attached algae studies of the Mississippi River at Monticello, Minnesota: Northern States Power Company, Monticello Nuclear Generating Plant Annual Report-1976, p. 2.1-1-2.1-64.

Krug, W.R., and Simon, B.D., 1991, Wisconsin floods and droughts, in Paulson, R.W., Chase, E.B., Roberts, R.S., and Moody, D.W., eds., National Water Summary 1988-1989-Hydrologic Events and Floods and Droughts: U.S. Geological Survey Water-Supply Paper 2375, p. 567-574.

Kuehn, J.H., Niemuth, Wallace, and Peterson, A.R., 1961, A biological reconnaissance of the Upper St. Croix River: Minnesota Department of Conservation and Wisconsin Department of Conservation, Investigations Report no. 239, 25 p.

Landon, M.K., and Delin, G.N., 1995, Ground-water quality in agricultural areas, Anoka Sand Plain aquifer, east-central Minnesota: U.S. Geological Survey Water-Resources Investigations Report 95$4024,25 \mathrm{p}$.

Larson-Higdem, Dana, Larson, S.P., and Norvitch, R.F., 1975 , Configuration of the water table and distribution of downward leakage to the Prairie du Chien-Jordon aquifer in the Minneapolis-St. Paul metropolitan area, Minnesota: U.S. Geological Survey Open-File Report 75-342, 29 p.

Leete, J.H., 1991, Ground-water quality and management in Minnesota: Journal of the Minnesota Academy of Science, v. 56, no. 1, p. 3443.

Lindholm, G.F., Helgesen, J.O., Broussard, W.L., and Ericson, D.W., 1974a, Water resources of the Snake River watershed, east-central Minnesota: U.S. Geological Survey Hydrologic Investigations Atlas HA-488, 3 sheets, scales 1:250,000 and 1:500,000.

Lindholm, G.F., Helgesen, J.O., Broussard, W.L., and Farrell, D.F., 1974b, Water resources of the Lower St. Croix River watershed, east-central Minnesota:
U.S. Geological Survey Hydrologic Investigations Atlas HA-490, 3 sheets, scales 1:250,000 and $1: 500,000$.

Lindholm, G.F., and Norvitch, R.F., 1976, Ground water in Minnesota: U.S. Geological Survey Open-File Report 76-354, 100 p.

Lindholm, G.F., Oakes, E.L., Ericson, D.W., and Helgesen, J.O., 1972, Water resources of the Crow Wing River watershed, central Minnesota: U.S. Geological Survey Hydrologic Investigations Atlas HA-380, 4 sheets, scale 1:250,000.

Linsley, R.K., Kohlor, M.A., and Paulhus, J.L.H., 1982, Hydrology for Engineers, 3rd ed., McGraw-Hill, Inc., $508 \mathrm{p}$.

Lorenz, D.L., and Payne, G.A., 1989, Selected data describing stream subbasins in the Redwood River Basin, southwestern Minnesota: U.S. Geological Survey Open-File Report 89-405, 5 p., 1 sheet, scale 1:100,000.

1991a, Selected data for stream subbasins in the Le Sueur River Basin, south-central Minnesota: U.S. Geological Survey Open-File Report 91-62, 8 p., 1 sheet, scale 1:100,000.

$1991 \mathrm{~b}$, Selected data for stream subbasins in the Watonwan River Basin, south-central Minnesota: U.S. Geological Survey Open-File Report 91-61, 7 p., 1 sheet, scale 1:100,000.

1992, Physical characteristics of stream subbasins in the Blue Earth River Basin, south-central Minnesota and north-central Iowa: U.S. Geological Survey Open-File Report 91-512, 10 p., 1 sheet, scale 1:100,000.

1994, Physical characteristics of stream subbasins in the Pomme de Terre River Basin, west-central Minnesota: U.S. Geological Survey Open-File Report 93-47, 8 p., 1 sheet, scale 1:100,000.

Lorenz, D.L., Sanocki, C.A., and Winterstein, T.A., 1994, Physical characteristics of stream subbasins in the Lac qui Parle River Basin, southwest Minnesota and eastern South Dakota: U.S. Geological Survey Open-File Report 93-46, 12 p., 1 sheet, scale 1:100,000. 
Lower St. Croix Management Commission, 1990, Annotated research bibliography-St. Croix River, Minnesota and Wisconsin, variously paged.

Lubinski, K.S., Carmody, G., Wilcox, D., and Drazkowski, B., 1991, Development of water level regulation strategies for fish and wildlife, Upper Mississippi River System: Regulated Rivers Research and Management, v. 6, no. 2, p. 117-124.

Lubinski, K.S., Vooren, A., Farabee, G., Janecek, J., and Jackson, S.D., 1986, Common carp in the Upper Mississippi River: Hydrobiologia, v. 136, p. 141154.

Luttenton, M.R., and Rada, R.G., 1986, Effects of disturbance on epiphytic community architecture: Journal of Phycology, v. 22, no. 3, p. 320-326.

Mandle, R.J., and Konitz, A.L., 1992, Simulation of regional ground-water flow in the CambrianOrdovician aquifer system in the northern midwest United States: U.S. Geological Survey Professional Paper 1405-C, 97 p.

Maschwitz, D.E., 1984, Establishment of an ammonia effluent limitation for the Twin Cities metro plant, in Wiener, J.G., Anderson, R.V., and McConville, D.R., eds., Contaminants in the Upper Mississippi River: Butterworth Publishers, Boston, Massachusetts, p. 261-278.

Mathiak, H.A., 1979, A river survey of the unionid mussels of Wisconsin, 1973-1977: Sand Shell Press, Horicon, Wisconsin, 75 p.

Metropolitan Council, 1992, Twin Cities metropolitan area water supply-A plan for action: Metropolitan Council 590-92-025, St. Paul, Minnesota, $72 \mathrm{p}$.

Metropolitan Waste Control Commission, 1993a, Mississippi River phosphorus study reportSummary and recommendations: St. Paul, Minnesota, 43 p.

1993b, Mississippi River phosphorus study report-Water quality of the Mississippi River and its tributaries (1976-1991): St. Paul, Minnesota, $18 \mathrm{p}$. 1993c, Mississippi River phosphorus study report-Point and nonpoint source contributions: St. Paul, Minnesota, 66 p.

1993d, Mississippi River phosphorus study report-River and lake sediment: St. Paul, Minnesota, variously paged.

1994b, Water quality analysis of the Lower Minnesota River and selected tributaries-River (1976-1991) and nonpoint source (1989-1992) monitoring, volume 1: St. Paul, Minnesota, $142 \mathrm{p}$.

Meyer, G.N., and Swanson, L., eds. 1992, Geologic atlas, Ramsey County, Minnesota: Minnesota Geological Survey County Atlas C-7, 10 plates.

Minnesota Department of Health, 1964, Report on investigation of the Lower Minnesota River and tributaries from Carver Rapids to the mouthAugust 1963 to February 1964: Division of Environmental Health, Section of Water Pollution Control, St. Paul, Minnesota, 103 p.

1985, Volatile organic survey of community water supplies-Report to the Legislative Commission on Minnesota Resources: Minnesota Department of Health, Section of Water Supply and Engineering, Minneapolis, Minnesota, 23 p.

Minnesota Department of Natural Resources, 1989, Drought of 1988: Division of Waters Report no. 500-1/89, St. Paul, Minnesota, 46 p.

Minnesota Department of Natural Resources, Division of Waters, 1961, Water resources of the Minneapolis-St. Paul metropolitan area: Minnesota Department of Conservation, Division of Waters Bulletin 11, $52 \mathrm{p}$.

Minnesota Pollution Control Agency, 1986, Ground water in Minnesota: A user's guide to understanding Minnesota's ground-water resource: St. Paul, Minnesota, p. 47.

1989, Review of water quality conditions in Lake Pepin for the summer of 1988: Minnesota Pollution Control Agency, St. Paul, Minnesota, variously paged.

1993a, Mississippi River phosphorus study report—Lake Pepin water quality (1976-1991): St. Paul, Minnesota, 105 p. 
1993b, Mississippi River phosphorus study report—Lake Pepin water quality (1976-1991): St. Paul, Minnesota, 105 p.

1993c, Mississippi River phosphorus study report-Lake Pepin and Mississippi River BATHTUB modeling: St. Paul, Minnesota, 62 p.

1993d, Mississippi River phosphorus study report-Benefits inventory report: St. Paul, Minnesota, variously paged.

1994a, Minnesota River Assessment Project Report: St. Paul, Minnesota, 15 p.

1994b, Minnesota River Assessment Project reports, v. I, Legislative Commission on Minnesota Resources work plan and project summary: St. Paul, Minnesota, variously paged.

1994c, Minnesota River Assessment Project reports, v. II, physical and chemical assessment: St. Paul, Minnesota, variously paged.

1994d, Minnesota River Assessment Project reports, v. III, biological and toxicological assessment: St. Paul, Minnesota, variously paged.

1994e, Minnesota River Assessment Project reports, v. IV, land use assessment: St. Paul, Minnesota, variously paged.

Montz, G.R., Renard, P.A., Hanson, S.R., and Enblom, J.W., 1989, Biological survey of the St. Croix River: Minnesota Department of Natural Resources, Division of Wildlife, Special Publication, variously paged.

Moyle, J.B., 1940, A biological survey of the Upper Mississippi River system: Minnesota Department of Conservation, Fisheries Research Investigational Report no. 10,69 p.

Mudrey, M.G., Jr., LaBarge, G.A., Myers, P.E., and Cordua, W.S., 1987, Bedrock geology of Wisconsin, Wisconsin Geological and Natural History Survey Map 87-11a, 2 sheets.

Mueller, Lisa, 1993, Winged mapleleaf mussel and Higgin's Eye pearly mussel freshwater mussels threatened with extinction: Minnesota Department of Agriculture, $19 \mathrm{p}$.
National Biocentric, Inc., 1979, A baseline inventory of the aquatic community in the Mississippi River, submitted to the Metropolitan Waste Control Commission, variously paged.

Nord, R.C., 1976, A compendium of fishery information on the Upper Mississippi River: Upper Mississippi River Conservation Committee Special Publication, $238 \mathrm{p}$.

Northern States Power Company, 1971, Evaluation of attached algae in the Mississippi River adjacent to the Northern States Power Sherburne County Generating Plant, Becker, Minnesota, during October and November, 1971, in Initial Survey of the Sherburne County Generating Plant SiteTerrestrial and aquatic biology: Northern States Power Company, Minneapolis, Minnesota, p. 1-5.

Norvitch, R.F., Ross, T.G., and Brietkrietz, Alex, 1973, Water resources outlook for the Minneapolis-St. Paul Metropolitan Area, Minnesota: Metropolitan Council of the Twin Cities area, St. Paul, Minnesota, $219 \mathrm{p}$.

Novitzki, R.P., Van Voast, W.A., and Jerabek, L.A., 1969, Water resources of the Yellow Medicine River watershed, southwestern Minnesota: U.S. Geological Survey Hydrologic Investigations Atlas HA-320, 3 sheets, scale 1:250,000.

Oakes, E.L., and Bidwell, L.E., 1968, Water resources of the Mississippi headwaters watershed, northcentral Minnesota: U.S. Geological Survey Hydrologic Investigations Atlas HA-278, 4 sheets, scale $1: 250,000$.

Oh1, Lloyd, 1992, Mississippi River phosphorus study report-Historical trends in the trophic state of Lake Pepin: University of Wisconsin-Eau Claire, Department of Biology, 21 p.

Olcott, P.G., 1992, Ground-water atlas of the United States, segment 9, Iowa, Michigan, Minnesota, and Wisconsin: U.S. Geological Survey Hydrologic Investigations Atlas 730-J, 31 p., scales 1:250,000 and 1:500,000.

Olson, K.N., and Meyer, M.P., 1976, Vegetation, land and water surfaces changes in the upper navigable portion of the Mississippi River Basin over the period 1939-1973: University of Minnesota, 
Institute of Agriculture, Forestry, and Home Economics, Remote Sensing Laboratory, Research Report No. 96-4, 225 p.

Palen, B.M., Kanivetsky, Roman, and Christopher, R.A., 1993, Water-table hydrogeology, in Meyer, G.N., and Falteisek, J., eds., Regional hydrogeologic assessment Anoka Sand PlainAnoka, Chisago, Isanti, and Sherburne Counties, Minnesota: Minnesota Department of Natural Resources, Regional Hydrogeologic Assessment RHA-1, 1 plate, 1 sheet, 1:200,000.

Parrett, C., Melcher, N.B., and James, R.W., 1993, Flood discharges in the Upper Mississippi River Basin, 1993: U.S. Geological Circular 1120-A, $14 \mathrm{p}$.

Payne, G.A., 1991, Sediment, nutrients, and oxygendemanding substances in the Minnesota RiverSelected water-quality data, 1989-90: U.S. Geological Survey Open-File Report 91-498, 37 p.

1994, Sources and transport of sediment, nutrients, and oxygen-demanding substances in the Minnesota River Basin, 1989-92: U.S. Geological Survey Water-Resources Investigations Report 934232, $71 \mathrm{p}$.

Pitlo, John, Jr., VanVooren, Al, and Rasmussen, Jerry, 1995, Distribution and relative abundance of Upper Mississippi River fishes: Upper Mississippi River Conservation Committee, Fish Technical Section Report, Rock Island, Illinois, p. 20.

Poff, N.L., and Allan J.D., 1995. Functional organization of stream fish assemblages in relation to hydrologic variability: Ecology, v. 76, no. 2, p. 606-627.

Proctor, B., 1993, Characterization of sediments settleable solids and water quality of stormwater runoff in the Minnesota River watershed: Water Resources Center, Mankato State University, Mankato, Minnesota, variously paged.

Rada, R.G., Wiener, J.G., Bailey, P.A., and Powell, D.E., 1990, Recent influxes of metals into Lake Pepin, a natural lake on the Upper Mississippi River: Archives of Environmental Contamination and Toxicology, v. 19, no. 5, p. 712-716.
Rasmussen, J.L., 1979, A compendium of fishery information on the Upper Mississippi River: Upper Mississippi River Conservation Committee Special Publication, 2nd ed., 259 p.

Reeder, H.O., 1966, Fourteen maps of parts of the ground-water reservoir in the Minneapolis-St. Paul metropolitan area: U.S. Geological Survey OpenFile Maps.

Richards, Carl, Kutka, F.J., 1993, Diatom assemblage structure as an indicator of stream habitat condition in the Minnesota River Watershed: Natural Resources Research Institute Technical Report Series NRRI/TR-92/23, 45 p.

Ruhl, J.F., 1987, Hydrogeologic and water-quality characteristics of glacial-drift aquifers in Minnesota: U.S. Geological Survey WaterResources Investigations Report 87-4224, 2 plates. 1994, Quality of ground water around Vadnais Lake and in Lambert Creek watershed, and interaction of ground water with Vadnais Lake, Ramsey County, Minnesota: U.S. Geological Survey Water-Resources Investigations Report 94$4062,59 \mathrm{p}$.

Ruhl, J.F., and Wolf, R.J., 1983, Hydrogeologic and water-quality characteristics of the St. Peter aquifer, southeast Minnesota: U.S. Geological Survey Water-Resources Investigations Report 834200,2 plates.

1984, Hydrogeologic and water-quality characteristics of the Upper Carbonate aquifer, southeast Minnesota: U.S. Geological WaterResources Investigations Report 84-4150, 2 plates.

Ruhl, J.F., Wolf, R.J., and Adolphson, D.G., 1982, Hydrogeologic and water-quality characteristics of the Ironton-Galesville aquifer: U.S. Geological Survey Water-Resources Investigations Report 824080, 2 plates.

Ruhl, J.F., Wolf, R.J., and Adolphson, D.G., 1983, Hydrogeologic and water-quality characteristics of the Prairie du Chien-Jordan aquifer, southeast Minnesota: U.S. Geological Survey WaterResources Investigations Report 83-4045, 2 plates. 
Sanocki, C.A., 1995a, Physical characteristics of stream subbasins in the Upper Minnesota River Basin, west-central Minnesota, northeastern South Dakota, and southeastern North Dakota: U.S. Geological Survey Open-File Report 95-162, 16 p., 1 sheet, scale 1:100,000.

1995b, Physical characteristics of stream subbasins in the Cottonwood River Basin, southwestern Minnesota: U.S. Geological Survey Open-File Report 95-333, 14 p., 1 sheet, scale 1:100,000.

Sanocki, C.A., and Krumrie, J.R., 1994, Physical characteristics of stream subbasins in the Chippewa River Basin, west-central Minnesota: U.S. Geological Survey Open-File Report 94-488, 16 p., 1 sheet, scale 1:100,000.

Scheld, Janie, Froehlig, Tim, Chaffee, Cindy, Goldenstein, Tony, Kassen, John, Ellstrom, James, Schmidt, Annette, Fairchild, M.G., McCormick, M.A., Schmisek, S.J., Childs, L.S., Arulanandam, Bernard, Mott, Eric, Stein, David, Kleist, Tom, Miller, Benjamin, Kujawa, Tom, Marks, Tom, and Mercurio, S.D., 1993, Assessment of impact of organic pollutants on fish in the Minnesota River watershed by hepatic aminopyrine n-demethylase activity: Water Resources Center, Mankato State University, Mankato, Minnesota, 77 p.

Scherer, H.P., 1970, A fish study on the Mississippi River at Monticello, Minnesota: Master's Thesis, St. Cloud State College, St. Cloud, Minnesota, $75 \mathrm{p}$.

Schlosser, I.J., and Ebel, K.K., 1989, Effects of flow regime and cyprinid predation on a headwater stream: Ecological Monographs, v. 59, no. 1 p. 4157.

Schneider, J.A., 1966, A biological reconnaissance of the Minnesota River from Lac qui Parle Dam to Mankato: Minnesota Department of Conservation Division of Game and Fish, Section of Technical Services, Special Publication 37, 47 p.

Schoenberg, M.E., 1984, Water levels and water-level changes in the Prairie du Chien-Jordan and Mount Simon-Hinckley aquifers, Twin Cities metropolitan area, Minnesota, 1971-80: U.S. Geological Survey Water Resources Investigations Report 83-4237, 23 p.

1989, Factors affecting water-supply potential of the Twin Cities metropolitan area aquifer system: Journal of the Minnesota Academy of Science, v. 55 , no. 1 , p. $38-47$.

1990, Effects of present and projected groundwater withdrawals on the Twin Cities aquifer system, Minnesota: U.S. Geological Survey Water-Resources Investigations Report 90-4001, $165 \mathrm{p}$.

Siegel, D.I., 1989, Geochemistry of the CambrianOrdovician aquifer system in the northern midwest United States: U.S. Geological Survey Professional Paper 1405-D, 76 p.

Sims, P.K., and Morey, G.B., eds., 1972, Geology of Minnesota-A centennial volume: Minnesota Geological Survey, 632 p.

Southard, R., 1993, Flood volumes in the Upper Mississippi River Basin, April 1 through September 30, 1993: U.S. Geological Survey Circular 1120-H, 32 p.

Southern Minnesota River Basin Commission, 1977, Minnesota River Basin report: Southern Minnesota River Basin Commission, Minnesota State Legislature 1141.01, variously paged.

Steingraeber, M.T., Schwartz, T.R., Wiener, J.G., and Lebo, J.A., 1994, Polychlorinated biphenyl congeners in emergent mayflies from the Upper Mississippi River: Environmental Science and Technology, v. 28, no. 4, p. 707-714.

Steingraeber, M.T., and Wiener, J.G., 1995, Bioassessment of contaminant transport and distribution in aquatic ecosystems by chemical analysis of burrowing mayflies (Hexagenia), Regulated Rivers: Research and Management, v. 2, no. 2, p. 201-209.

Swanson, L, and Meyer, G.N., eds., 1990, Geologic atlas, Washington County, Minnesota: Minnesota Geological Survey County Atlas C-5, 7 plates. 
Swenson, W.A., Heberling, G.D., Orr, D.J., and Simonson, T.D., 1989, Fishery resources of the Upper Mississippi River and relationship to stream discharge: Journal of the Minnesota Academy of Science, v. 55, no. 1, p. 144-149.

Troelstrup, N.H., Foley, J.L., and Perry, J.A., 1993a, An examination of large woody debris accumulations in the Lower St. Croix National Scenic Riverway: Legislative Commission on Minnesota Resources Work Element B.4., 49 p.

1993b, Changing patterns of water quality and biology within the lower St. Croix National Scenic Riverway: Legislative Commission on Minnesota Resources Work Element B.2 and B.6, 162 p.

Trotta, L.C., 1996, Water use in Minnesota, 1990: Minnesota Department of Natural Resources Water-Use Map Series, 1 sheet.

Underhill, J.C., 1989, The distribution of Minnesota fishes and late Pleistocene glaciation: Journal of the Minnesota Academy of Sciences, v. 55, no. 1, p. 32-37.

U.S. Army Corps of Engineers, 1990, Mississippi River headwaters lakes in Minnesota-Low flow review: St. Paul, Minnesota, variously paged.

U.S. Environmental Protection Agency, 1994, National primary drinking water standards: Environmental Protection Agency, 810-F-94-001A, 4 p.

Van Voast, W.A., Broussard, W.L., and Wheat, D.E., 1972, Water Resources of the Minnesota RiverHawk Creek watershed, southwestern Minnesota: U.S. Geological Survey Hydrologic Investigations Atlas HA-391, 3 sheets, scale 1:250,000.

Van Voast, W.A., Jerzbek, L.A., and Novitzki, R.P., 1970, Water resources of the Redwood River watershed, southwestern Minnesota: U.S. Geological Survey Hydrologic Investigations Atlas HA-345, 3 sheets.

Wahl, K.L., Vining, K.C., and Wiche, G.J., 1993, Precipitation in the upper Mississippi River Basin, January 1 through July 31, 1993: U.S. Geological Survey Circular, 1120-B, 13 p.
Wiebe, A.H., 1927, Biological survey of the Upper Mississippi River, with special reference to pollution: Bulletin of the U.S. Bureau of Fisheries, no. 43, part 2, p. 137-167.

Wiener, J.G., Jackson, G.A., May, T.W., and Cole, B.P., 1984, Longitudinal distribution of trace elements (As, $\mathrm{Cd}, \mathrm{Cr}, \mathrm{Hg}, \mathrm{Pb}$, and $\mathrm{Se}$ ) in fishes and sediments in the Upper Mississippi River, in Wiener, J.G., Anderson, R.V., and McConville, D.R., eds., Contaminants in the Upper Mississippi River: Butterworth Publishers, Boston, Massachusetts, p. 139-170.

Wiener, J.G., and Spry, D.J., 1995, Toxicological significance of mercury in freshwater fish, in Heinz, G., and Beyer, N., eds., Interpreting environmental contaminants in animal tissues, Lewis Publishers, Boca Raton, Florida, p. 1-39.

Wilson, D.M., Naimo, T.J., Wiener, J.G., Anderson, R.V., Sandheinrich, M.B., and Sparks, R.E., 1995, Declining populations of the fingernail clam Musculium transversum in the Upper Mississippi River: Hydrobiologia, v. 304, p. 209-220.

Winterstein, T.A., 1982, Annotated report and data inventory for the Mississippi and Minnesota Rivers, Minneapolis-St.Paul metropolitan area: U.S. Geological Survey Open-File Report 82-869, $99 \mathrm{p}$.

Wolf, R.J., Ruhl, J.F., and Adolphson, D.G., 1983, Hydrogeologic and water-quality characteristics of the Mount Simon-Hinckley aquifer, southeast Minnesota: U.S. Geological Survey WaterResources Investigations Report 83-4031, 2 plates.

Woodward, D.G., 1986, Hydrogeologic framework and properties of regional aquifers in the Hollandale Embayment, southeastern Minnesota: U.S. Geological Survey Hydrologic Investigations Atlas HA-677, 2 sheets, scales 1:1,000,000 and 1:200,000.

Woodward, D.G., and Anderson, H.W., Jr., 1986, Hydrogeologic and water-quality characteristics of the Cretaceous aquifer, southwestern Minnesota: U.S. Geological Survey Water-Resources Investigations Report 84-4153, 2 plates. 
Young H.L., 1992a, Hydrology of the Cambrian-

Ordovician aquifer system in the northern midwest, United States: U.S. Geological Survey Professional Paper 1405-B, 99 p.

1992b, Summary of ground-water hydrology of the Cambrian-Ordovician aquifer system in the northern midwest, United States: U.S. Geological Survey Professional Paper 1405-A, 55 p.

Young, H.L., and Hindall, S.M., 1973, Water resources of Wisconsin, St. Croix River Basin: U.S. Geological Survey Hydrologic Investigations Atlas HA-451, 4 sheets.

Zischke, J.A., Ericksen, Gerald, Waller, Dianne, and Bellig, Robert, 1993, Analysis of benthic macroinvertebrate communities in the Minnesota River watershed: Department of Biology, St. Olaf College, Northfield, Minnesota, $82 \mathrm{p}$. 